\title{
Irrationele bestuurders en corporate governance
}

Abe de Jong

SAMENVATTING Topmanagers van ondernemingen hebben een grote invloed op de investeringen en financiering van de ondernemingen die zij leiden. Volgens de economische agentprincipaal theorie zullen rationele managers hun eigenbelang nastreven, zelfs als dit ten koste van aandeelhouders en andere belanghebbenden gaat. De literatuur op het gebied van corporate governance beschrijft de werking en effectiviteit van mechanismen om deze agency-problemen in te perken. Recente studies op het gebied van behavioral corporate finance tonen echter aan dat managers niet altijd rationeel handelen en dat deze irrationaliteit meetbare negatieve invloed kan hebben op strategische beslissingen. De vraag die in dit artikel centraal staat is welke invloed corporate governance kan hebben in het verminderen van de negatieve effecten van irrationeel gedrag van managers.

\section{Inleiding}

Corporate governance gaat over goed ondernemingsbestuur en is dus een onderwerp dat relevant is sinds het bestaan van ondernemingen. Door recente schandalen bij grote beursondernemingen en de gevolgen hiervan zijn bestuurders, beleggers, beleidsmakers en wetenschappers geconfronteerd met het belang van goed bestuur. In de bestaande wetenschappelijke literatuur over corporate governance en ondernemingsfinanciering wordt over het algemeen verondersteld dat managers rationeel handelen. Deze assumptie heeft een belangrijke rol in de ontwikkeling van het vakgebied gespeeld. Theorievorming door micro-

Prof. dr Abe de Jong is als hoogleraar ondernemingsfinanciering en corporate governance verbonden aan RSM Erasmus University (ajong@rsm.nl). economische modellen en empirische toetsen van deze theorie beschrijven een scala van effecten van corporate governance op ondernemingen.

In recente bijdragen aan de literatuur over ondernemingsfinanciering, in de zogenaamde behavioral corporate finance literatuur, is aangetoond dat topbestuurders naast rationele overwegingen ook irrationele drijfveren in hun besluitvorming kunnen meewegen. In deze bijdragen wordt aangetoond dat irrationeel gedrag negatieve gevolgen kan hebben, zoals vernietiging van ondernemingswaarde. In dit artikel wordt ingegaan op de gevolgen van irrationeel gedrag van bestuurders op de effectiviteit van corporate governance-mechanismen. Met andere woorden, in welke mate zijn corporate governance-structuren uitgerust om de negatieve gevolgen van irrationele besluitvorming te beperken?

In paragraaf 2 wordt een inleiding gegeven over de rationele, economische fundamenten van corporate governance. Vervolgens wordt in paragraaf 3 beschreven op welke wijze managers irrationeel kunnen zijn en hoe hun irrationaliteit significante invloed op financiële en strategische beslissingen kan hebben. In paragraaf 4 wordt beargumenteerd welke invloed het vervangen van de veronderstelling van rationaliteit heeft op governance. Met andere woorden: wat is de invloed van irrationeel gedrag door topbestuurders op de optimale corporate governance-structuur van een onderneming? Paragraaf 5 bevat de conclusies.

\section{Corporate governance en rationele managers}

Ondernemingsfinanciering is een discipline binnen de economische wetenschap. Het is dan ook niet vreemd dat de huidige literatuur is gestoeld op economische fundamenten. Het uitgangspunt van de huidige corporate governance-literatuur is de agentprincipaal theorie, een theoretisch beeld van een onderneming, als een knooppunt van contracten. Deze theorie is gebaseerd op de inzichten van onder andere Berle en Means' (1932) analyse van 
Amerikaanse beursondernemingen, waarin het eigendom in handen is van een groep van aandeelhouders, die ieder soms slechts een klein belang in de ondernemingen hebben en niet meer betrokken zijn bij de activiteiten van de onderneming. De leiding is in handen van professionele managers, die door de spreiding van het aandelenbezit niet of nauwelijks door aandeelhouders worden gecontroleerd. Berle en Means constateren dat het risico bestaat dat de managers hun macht misbruiken ten koste van de aandeelhouders, doordat een belangentegenstelling tussen managers en aandeelhouders aanwezig is en de aandeelhouders niet in staat zijn voldoende toezicht op de managers uit te oefenen. Hoewel de observatie in de literatuur aan Berle en Means wordt toegeschreven dient niet onvermeld te blijven dat Polak in 1931 stelde: "In dit stadium heeft een grote ommekeer in de verhoudingen plaats. Onder de aandeelhouders komen er steeds meerdere die geenerlei anderen band met de vennootschap en haar leiders onderhouden dan dien van het aandeelhouderschap" en "Zoodoende worden de bestuurders en commissarissen schijnbaare onbeperkte heerschers in de onderneming." (p. 16 en 17).

Jensen en Meckling (1976) hebben de gedachtegang van Berle en Means geformaliseerd in de vorm van de agent-principaal theorie. Deze theorie veronderstelt dat een manager van een onderneming een agent is van de aandeelhouders, de principalen. Managers van ondernemingen proberen hun welvaart te optimaliseren en dit impliceert - indien zij rationeel zijn - dat zij hun inspanningen zullen minimaliseren en maximale geldelijke en niet-geldelijke beloning proberen te realiseren. Hiermee is een belangentegenstelling geboren, aangezien voor aandeelhouders juist een maximale inspanning tegen een minimale beloning de investeringen meer waardevol maakt. Indien de aandeelhouders imperfecte informatie hebben over de inspanning en beloning van managers ontstaat een agency-conflict. Het vertrekpunt van Jensen en Meckling's redenering is de ondernemer die zowel manager als eigenaar is. In deze situatie is er geen scheiding van leiding en eigendom en bestaat er dus geen agency-probleem. De aandeelhouder en manager zijn immers dezelfde persoon. Zodra de ondernemer een deel van zijn aandelen aan andere partijen aanbiedt of nieuwe aandelen aanbiedt in een beursgang, speelt mogelijk een moral hazard agencyconflict op. Immers, indien de ondernemer nog slechts een fractie van de aandelen bezit, wordt het aantrekkelijk om zijn inspanning te verminderen of de beloning te vergroten. De manager profiteert volledig, terwijl een deel van de kosten door de andere aandeelhouders wordt gedragen. Jensen en Meckling (1976, p. 312) noemen als specifieke voorbeelden van agency-kosten excessief salaris en niet-geldelijke beloningen, zoals de aantrekkelijkheid van de secretariële staf en een dure computer. Later is door Jensen (1986) ook nog overinvesteringsgedrag toegevoegd, waarbij managers groei van de onderneming nastreven, ongeacht of deze groei waarde creëert. Voor de managers is groei een rationeel doel, omdat hun welvaart stijgt door bijvoorbeeld een hogere beloning.

De rol van corporate governance is het verminderen van agency-conflicten. De meest bestudeerde governance-mechanismen zijn de identiteit, concentratie en zeggenschap van aandeelhouders, de samenstelling van de Raden van Bestuur en Commissarissen, de dreiging van een onvrijwillige overname, en de beloningsstructuur van de topmanagers. ${ }^{1}$ De zin van corporate governance is gelegen in het bestaan van potentiële agency-conflicten en dus alleen relevant voor ondernemingen met scheiding van leiding en eigendom. Om deze reden worden met name aan een aandelenbeurs genoteerde ondernemingen bestudeerd, die per definitie deze scheiding hebben. De benadering uitgaande van rationele managers en de hieruit volgende agency-conflicten heeft de literatuur veel zinvolle theorievorming opgeleverd en interessante empirische toetsen (Shleifer en Vishny, 1997). Zo kan het bijvoorbeeld waardevol zijn om een klein aantal aandeelhouders te hebben die een groot belang in de onderneming hebben. Zij hebben immers de macht om managers te beïnvloeden en profiteren ook in grotere mate van betere prestatie dan kleine aandeelhouders. Tevens is het waardevol om managers te belonen met aandelen, omdat zij naarmate hun aandelenbezit groter is meer overeenkomstige belangen met de aandeelhouders hebben. In eerste instantie richtten onderzoekers zich op individuele governance-kenmerken, terwijl in latere studies ook relaties tussen governance-karakteristieken en de invloed op ondernemingsprestaties aandacht hebben gekregen (Becht, Bolton en Röell, 2003). Een studie die recentelijk veel aandacht heeft gekregen is een studie van Gompers, Ishii en Metrick (2003) waaruit blijkt dat andeelhoudersrechten een positieve invloed op de financiële prestaties van ondernemingen hebben. Deze resultaten wijzen op het belang van corporate governance, maar roepen ook veel vragen op. Een cruciale vraag is of een relatie tussen governance en prestaties kan worden geïnterpreteerd vanuit het perspectief van de agency-theorie. Ofwel, is de assumptie dat actoren in de governance-arena rationeel handelen reëel? 


\section{Irrationele managers}

In beursondernemingen waarin leiding en eigendom zijn gescheiden spelen topmanagers een belangrijke rol. In Nederland zijn dit de voorzitter en leden van de Raad van Bestuur en in Angelsaksische landen zijn dit de chief executive officer (CEO) en de executive board members. Deze personen hebben een belangrijke invloed op de strategische keuzes binnen ondernemingen. Bertrand en Schoar (2003) hebben over de periode tussen 1969 en 1999 in de 800 grootste Amerikaanse ondernemingen managers bestudeerd die in de top van twee of meer ondernemingen hebben gewerkt. Van deze en andere grote ondernemingen beschrijven de onderzoekers de invloed van individuele managers op de investeringspolitiek en het financieel beleid. De auteurs verklaren bijvoorbeeld het aantal acquisities van een onderneming in een jaar, aan de hand van de omvang en de winstgevendheid van de onderneming, maar ook indicatorvariabelen voor jaar, onderneming en topmanager. Door het opnemen van indicatoren voor individuele managers stijgt de verklaringskracht van het model van 0.25 naar $0.36 .^{2}$ Dit resultaat betekent dat de persoon aan de top medebepalend is voor de snelheid waarmee acquisities elkaar opvolgen. De auteurs concluderen dat de stijl van individuele topmanagers invloed heeft op de strategische en financiële koers van de onderneming. In deze paragraaf zal verder worden ingegaan op de oorzaken van irrationaliteit van managers (3.1) en op empirisch bewijs in de financieringsliteratuur (3.2).

\subsection{Oorzaken van irrationaliteit}

Waar de economische theorievorming over corporate governance veronderstelt dat deze invloedrijke actoren rationeel handelen, hebben psychologen een stortvloed aan bewijs geleverd dat beslissingen op vele manieren verstoord kunnen worden door irrationeel gedrag. Goede voorbeelden zijn te vinden in het werk van Kahneman en Tversky (2000) en Bazerman (1998), waarin tientallen kenmerken van menselijk gedrag worden opgesomd die leiden tot irrationele beslissingen. Hoewel de assumptie van rationaliteit niet realistisch is, impliceert dit niet per se dat irrationeel gedrag van managers tot waardevernietigende beslissingen leidt. De zogeheten behavioral corporate finance literatuur bestudeert de invloed van persoonskenmerken van beslissers op hun besluiten. ${ }^{3}$ Deze literatuur veronderstelt dat beslissers irrationele besluiten nemen, in de zin dat een strikt economische kosten-batenanalyse tot een ander besluit zou leiden. De literatuur valt op te delen in twee sterk verschil- lende onderdelen, waarin óf investeerders irrationeel zijn óf managers niet-rationele beslissingen nemen. Zoals Baker, Ruback en Wurgler (2004) in een recent overzichtsartikel tonen, veronderstelt het merendeel van de bestaande bijdragen dat investeerders irrationeel zijn en dat door imperfecte arbitrage de koersen van aandelen of obligaties geen correcte afspiegeling van de waarde zijn. Rationele managers zullen deze onder- of overwaardering herkennen en proberen te profiteren van de irrationele investeerders. In dit artikel is de situatie relevant waarin de manager irrationeel gedrag vertoont, om twee redenen. De eerste reden om managers te bestuderen is dat in een onderneming een klein aantal managers belangrijke beslissingen neemt en de invloed van een irrationeel handelend individu dus groot kan zijn. De tweede reden is dat de gevolgen van irrationele investeerders wellicht beperkt zijn doordat arbitragemogelijkheden in financiële markten relatief eenvoudig benut kunnen worden, door de liquiditeit van deze markten en de veelheid aan financiële instrumenten en diensten. Het arbitreren om te kunnen profiteren van waardevernietigende beslissingen van irrationele managers is slechts mogelijk door een groot belang te kopen of door een overname, hetgeen een grote investering vergt en risicovol is.

Het irrationele gedrag van managers dat in de bestaande studies aandacht krijgt, is overoptimisme en overmatig zelfvertrouwen. ${ }^{4}$ Psychologen beschrijven deze gedragingen aan de hand van het beterdan-gemiddeld-effect. Wanneer aan personen wordt gevraagd hun eigen kennis en kunde in te schatten, bestaat veelal de neiging tot zelfoverschatting ten opzichte van anderen. Bij managers kan dit gedrag zich vertalen in een zogenaamde illusie van controle, waarbij een beslisser de mogelijkheid overschat om de uitkomsten van een beslissing te beïnvloeden en hierdoor de kans op succes overschat. Hoewel het gebruik van de terminologie niet volledig consistent is, wordt normaal overoptimisme gedefinieerd als het overschatten van de kans op een positieve uitkomst en overmatig zelfvertrouwen als het overschatten van de opbrengsten van een keuze.

\subsection{Empirisch bewijs voor irrationaliteit}

Over het algemeen wordt de irrationaliteit van managers onderzocht in relatie tot grootschalige investeringen en in het bijzonder acquisities. ${ }^{5}$ Eén van de eerste bijdragen is Roll's (1986) hubris hypothese. Volgens Roll kunnen managers als gevolg van overmoed acquisities en overnames plegen waarbij de toekomstige bijdrage te positief wordt ingeschat. De irrationaliteit van topmanagers is het resultaat van 
overmatig optimisme en zelfvertrouwen. Het eerste formele model is ontwikkeld door Heaton (2002) en beschrijft een overoptimistische manager, waarbij overoptimisme overeenkomt met het onderschatten van de kans dat een investering verkeerd uitpakt en dus het overschatten van de kans of een goede afloop. De optimistische managers overschatten de waarde van toekomstige projecten en zullen dus ook projecten entameren die niet waardevol zijn. Anderzijds zijn de optimisten van mening dat de markt een te lage waardering toekent aan de aandelen van hun ondernemingen. Als gevolg hiervan zullen zij juist investeringsprojecten laten lopen indien externe financiering moet worden gezocht, omdat bij de uitgifte van nieuwe aandelen naar hun mening een te laag bedrag wordt ingelegd door aandeelhouders. ${ }^{6}$ De conclusie van dit model is dat optimistische managers relatief veel investeringen zullen financieren uit ingehouden winsten.

Malmendier en Tate (2005a) leveren empirisch bewijs dat managers irrationeel handelen en dat deze irrationaliteit beslissingen beïnvloedt. De auteurs bestuderen bijna 500 grote Amerikaanse beursondernemingen en construeren een creatieve maatstaf voor overmatig vertrouwen van de managers. In Amerikaanse beursondernemingen bezitten managers normaliter een groot of klein pakket aandelen en opties op aandelen. Tevens is hun persoonlijke welvaart via de inbreng van human capital verbonden met ondernemingsprestaties. Een rationele en dus risico-averse manager zal proberen het risico van veranderingen van de ondernemingswaarde op zijn persoonlijke welvaart te verminderen, bijvoorbeeld door niet onnodig lang opties aan te houden, maar deze optimaal uit te oefenen. Malmendier en Tate definiëren irrationele managers met overmatig vertrouwen als managers die te laat hun opties uitoefenen. Deze late uitoefening van managers reflecteert overoptimisme over toekomstige prestaties. Tevens meten de onderzoekers in welke mate de managers aandelen van hun eigen onderneming kopen. De maatstaven vertonen een sterke onderlinge samenhang en worden gebruikt om de hypothesen van Heaton (2002) te toetsen dat optimistische managers relatief veel investeringen financieren uit ingehouden winsten en dat optimistische managers vreemd vermogen prefereren boven eigen vermogen indien interne financiering ontoereikend is. Als eerste wordt de relatie gemeten tussen investeringen in vaste activa en beschikbare kasmiddelen en blijkt dat deze relatie significant sterker is bij de managers met overmatig vertrouwen. Deze bevinding impliceert dat de persoonskenmerken van managers investeringen beïnvloeden, waarbij irrationele overwegingen ratio- nele investeringsbesluiten verstoren. In verdere analyses vinden de auteurs dat voorgenoemd effect sterker is in ondernemingen die meer van extern eigen vermogen afhankelijk zijn. Managers die overoptimistisch zijn blijken eerder vreemd vermogen aan te trekken ter financiering indien interne kasmiddelen niet toereikend zijn.

Een tweede voorbeeld van empirisch bewijs betreft overnames. Malmendier and Tate (2005b) testen Roll's hubris hypothese door topmanagers te classificeren op basis van hun gedrag in het uitoefenen en bezit van opties en aandelen, en ook op basis van aandacht die zij in de media krijgen. De resultaten tonen dat managers met een overmatig vertrouwen vaker acquisities uitvoeren, waarbij de kans dat een dergelijke bestuurder een acquisitie uitvoert 65 procent groter is dan bij andere bestuurders. Ook leiden de aankondigingen tot meer negatieve reacties van aandeelhouders. Gemiddeld zijn de koersveranderingen bij aankondiging door een manager met overmatig zelfvertrouwen 70 tot 100 basispunten lager dan in het geval van managers waarbij geen overmatig zelfvertrouwen is vastgesteld. Deze empirische resultaten onderschrijven dat overmoedige managers te veel onrendabele acquisities uitvoeren.

Een laatste voorbeeld is de studie van Ang, De Jong en Van der Poel (2007) naar vertrouwdheid met bedrijfsonderdelen. Topmanagers die uiteindelijk verantwoordelijk zijn voor de strategie van een onderneming hebben tijdens hun carrière in een aantal andere ondernemingen en onderdelen van de eigen onderneming ervaringen opgedaan. Door deze ervaringen zijn managers van ondernemingen die uit meerdere divisies of segmenten bestaan, meer vertrouwd met bepaalde bedrijfsonderdelen dan met andere delen. Deze vertrouwdheid leidt mogelijk tot de illusie dat een betere controle over beslissingen mogelijk is. Als gevolg hiervan worden de kansen op succes en toekomstige winstgevendheid van deze onderdelen overschat. De onderzoeksvraag is of beslissers die meer vertrouwd zijn met bepaalde segmenten in hun onderneming bij de beslissing om een segment af te stoten een voorkeur hebben voor segmenten waarmee zij minder vertrouwd zijn. De resultaten voor een steekproef van Amerikaanse ondernemingen tonen aan dat rationele factoren een belangrijke deel van de keuzes kunnen verklaren, maar dat de bestuursvoorzitters een voorkeur hebben om geen segmenten af te stoten waar zij zelf eerder hebben gewerkt. Na correctie voor rationele overwegingen kiezen managers half zo vaak voor vertrouwde segmenten ten opzichte van de overige segmenten. Deze studie toont aan dat de achtergrond van een 
manager zijn besluitvorming mede beïnvloedt. De voorgaande beschrijving van irrationeel gedrag is gebaseerd op de recent in ontwikkeling gekomen behavioral corporate finance-literatuur. De resultaten van de studies in dit veld lijken twee conclusies te onderschrijven. Ten eerste blijken persoonskenmerken van beslissers, zoals overmatig zelfvertrouwen, van invloed te zijn op hun besluiten. Met andere woorden, naast rationele overwegingen spelen ook irrationele aspecten een rol in belangrijke beslissingen in ondernemingsfinanciering. Ten tweede zijn er indicaties dat de irrationele aspecten een negatieve invloed hebben op de prestaties van de onderneming. In de studie naar acquisitiegedrag leidt overmatig zelfvertrouwen tot negatieve effecten bij de aankondiging van een overname. Meer indirect bewijs is dat bij (des)investeringsbeslissingen rationele overwegingen, die ten doel hebben de prestaties te verbeteren, verstoord worden door irrationaliteit.

\section{Governance en irrationale managers}

In de standaard economische theorievorming onder de assumptie van rationele managers wordt verondersteld dat, indien managers onvoldoende worden gecontroleerd of onjuiste prikkels ontvangen, zij opportunistisch gedrag zullen vertonen dat ten koste van de financiers gaat. Corporate governance dient ter voorkoming van dergelijk gedrag, zoals fraude, diefstal en onvoldoende inzet. Indien de veronderstelling dat managers rationeel zijn wordt verlaten, wordt duidelijk dat managers ook zonder zich hiervan bewust te zijn beslissingen kunnen nemen die ten koste gaan van de prestaties en levensvatbaarheid van de onderneming. ${ }^{7}$ De vraag is dan welke rol corporate governance kan spelen in het optimaliseren van bestuur en toezicht van een onderneming, onder de veronderstelling dat actoren irrationeel kunnen handelen. Alvorens in subparagraaf 4.2 op deze vraag in te gaan, zal in subparagraaf 4.1 een tweetal positieve aspecten van irrationaliteit worden besproken.

\subsection{Positieve aspecten van irrationaliteit}

Het antwoord op de vraag welke invloed het verlaten van de veronderstelling dat managers rationeel zijn heeft op corporate governance kent als eerste een tweetal positieve aspecten van irrationele managers die de noodzaak van corporate governance zelfs verminderen: de rentmeestertheorie en risico-aversie. Davis, Schoorman en Donaldson (1997) beschrijven de rentmeestertheorie, als alternatief voor de economische agent-principaal theorie, op basis van de assumptie dat managers geen neo-klassieke nutsmaximliseerders zijn. In deze theorie zijn managers goede rentmeesters van de onderneming die het belang van betrokkenen, zoals financiers, werknemers en klanten, boven hun eigen belang stellen. Voor een econoom klinkt dergelijk gedrag wellicht naïef in de oren, maar er is legio empirisch bewijs voor deze rentmeestertheorie. Een aantal niet-representatieve voorbeelden zijn te vinden in Wennekes' (1993) boek over de aartsvaders van het Nederlandse bedrijfsleven. Mensen als Charles Stork van de gelijknamige machinefabriek en Jacques van Marken van de Nederlandsche Gist- en Spiritusfabriek zijn in de $19^{\mathrm{e}}$ eeuw ideaaltypen van deze rentmeesters. De ideeën achter de rentmeestertheorie ondermijnen de agent-principaal theorie, aangezien de belangentegenstelling tussen managers en andere belanghebbenden wegvalt. Rentmeesterschap is dus in economisch opzicht irrationeel, maar lost het agent-principaal probleem op. Helaas heeft de rentmeestertheorie geen invloed op de negatieve effecten van irrationaliteit zoals gedocumenteerd in de behavioral corporate finance-literatuur. Immers, goede bedoelingen helpen niet om onbedoelde verkeerde beslissingen te voorkomen.

Er is een tweede positief aspect van irrationaliteit van managers. Amihud en Lev (1981) beschrijven dat managers een groot risico lopen, omdat zij hun human capital en ook vaak aanzienlijke financiële middelen, in de onderneming hebben geïnvesteerd en hierdoor een slecht gespreide portefeuille bezitten. Deze positie leidt tot een grotere mate van risicoaversie dan vanuit economisch opzicht wenselijk. Met andere woorden, managers worden te voorzichtige ondernemers en zullen bijvoorbeeld proberen door acquisities hun bedrijven om te vormen tot gediversifieerde conglomeraten. Irrationeel optimisme en overmoedigheid kunnen voor deze managers de prikkel zijn om minder risico-avers te investeren en aldus de waarde van de onderneming te vergroten. Echter, hoewel slechts een beperkt aantal behavioral corporate finance-studies beschikbaar is, wijzen de empirische bevindingen erop dat de per saldo resterende negatieve effecten groot genoeg zijn om te meten. Blijkbaar zijn de bovengenoemde positieve effecten van irrationaliteit onvoldoende om de negatieve effecten weg te nemen. In de volgende subparagraaf zal de invloed van governance op het voorkomen van deze effecten worden toegelicht.

\subsection{De waarde van governance bij irrationele managers}

We kunnen concluderen dat de literatuur op het gebied van corporate governance heeft geleid tot analyses van de effectiviteit van mechanismen onder 
de veronderstellingen van agent-principaal theorie, waarin managers rationeel handelen. Doordat uit deze literatuur een goed inzicht is ontstaan in de werking van governance-mechanismen is het mogelijk om te beschrijven welke mechanismen het meest geschikt lijken om irrationele managers te beïnvloeden. ${ }^{8}$ Moerland (1997) maakt een onderscheid tussen enerzijds mechanismen die tot doel hebben de managers prikkels te geven om hen op een indirecte wijze te beïnvloeden om betere beslissingen te nemen, en anderzijds mechanismen waar een directe invloed op de beslissingen wordt uitgeoefend.

Een indrect mechanisme is de beloningsstructuur. Jensen en Meckling (1976) tonen reeds aan dat, indien de beloning van managers verbonden is aan de opbrengsten van de financiers, zij hun belangen zullen behartigen. Bijvoorbeeld, indien een manager aandelen bezit, is hij zelf aandeelhouder, en betaalt hij dus mee aan agency-kosten. Een vergelijkbare redenering geldt voor optiebeloning, hoewel hierbij opgemerkt dient te worden dat de relatie ingewikkelder is. Een manager die op basis van irrationele gronden financierings- en investeringsbeslissingen neemt zal niet worden gecorrigeerd door prikkels uit zijn beloningspakket, eenvoudigweg omdat hij niet beseft irrationele beslissingen te nemen. Beloning is dus in potentie een goed mechanisme ter vermindering van agency-kosten, maar niet zinvol ter voorkoming van irrationele besluiten. Hierbij dient opgemerkt te worden dat in het geval van specifieke vormen van irrationaliteit er wel een effect kan ontstaan. Zo leidt bijvoorbeeld overoptimisme tot een onderschatting van risico, terwijl de waarde van een optiepakket ook positief samenhangt met de risico's van de onderneming. In dit geval versterkt de beloningsstructuur irrationeel gedrag. Ook voor alle andere indirecte mechanismen, zoals de dreiging vanuit de markt voor vijandige overnames en de disciplinerende werking van vreemd vermogen, geldt dat naar verwachting de effecten zeer klein zullen zijn. Immers, een irrationeel handelende manager is zichzelf niet bewust van negatieve gevolgen van zijn besluiten, en dus zullen indirecte prikkels niet het gewenste effect sorteren.

Het meest directe mechanisme is het toezichthoudend orgaan, in Nederlandse en andere continentaalEuropese ondernemingen de Raad van Commissarissen en in Angelsaksische landen de non-executives van de board of directors. De rol van deze toezichthouders heeft twee goede uitgangspunten voor het inperken van de invloed van irrationele bestuurders. Ten eerste is het de taak van dit orgaan om toezicht te houden op het beleid van de bestuurders en de algemene gang van zaken. Deze taak is bijvoorbeeld in de
Nederlandse wet vastgelegd en de beide commissies voor corporate governance - de Commissie Peters in 1997 en de Commissie Tabaksblat in 2003 - hebben heldere aanbevelingen beschreven voor een goed functionerend toezicht. De tweede van veertig aanbevelingen van de Commissie Peters is dan ook: "De Raad van Commissarissen dient zodanig te zijn samengesteld dat de leden ten opzichte van elkaar en de Raad van Bestuur onafhankelijk en kritisch opereren." (p. 34). In de Code Tabaksblat is deze aanbeveling bijna letterlijk als principe III.2 opgenomen. Het tweede uitgangspunt is dat de toezichthouders, als enige partij buiten de bestuurders, volledig geïnformeerd kunnen worden, omdat alle rapportage vertrouwelijk zal worden behandeld. Door deze informatievoorsprong zijn de commissarissen in de ideale positie om voorstellen van bestuurders te toetsen op de rationaliteit van hun motivatie.

Bij de positie van de commissarissen kan een drietal kanttekeningen worden geplaatst. Als eerste is in het continentaal-Europese two-tier-systeem een expliciete scheiding aangebracht tussen bestuur en toezicht - in Nederland tussen bestuurders en commissarissen. In Angelsaksische landen hebben ondernemingen een one-tier-systeem, waarbij de executives en de non-executives gezamenlijk het toporgaan vormen. Gezien het belang van een kritische en onafhankelijke toezichthouder biedt de expliciete scheiding in het two-tier-systeem een beter uitgangspunt dan het onetier-systeem. Nederlandse ondernemingen hebben dus in dit opzicht een voorsprong ten opzichte van hun Angelsaksische concurrenten.

De tweede kanttekening die geplaatst dient te worden is triviaal: de toezichthouder dient in staat en bereid te zijn om kritisch ten opzichte van de bestuurders te opereren. De governance codes in Nederland en buitenland alsmede de academische literatuur zijn unaniem in de noodzakelijke randvoorwaarden. Toezichthouders dienen onafhankelijk en deskundig te zijn en over voldoende tijd voor hun taak te beschikken. ${ }^{9}$ De uitgebreide regelgeving op het gebied van governance, zeker voor ondernemingen die in meerdere landen een beursnotering hebben en dus met meerdere regelgevers te maken hebben, lijkt veel aandacht van toezichthouders te vergen. Een recente studie van Ernst \& Young (2006) beschrijft van 148 toezichthouders uit 16 verschillende landen hun visie op risico. Van deze respondenten geeft 71 procent aan dat risico's voor de onderneming de afgelopen jaren zijn toegenomen, waarna 32 procent van deze groep spontaan aangeeft dat risico's van het niet-naleven van regels de belangrijkste oorzaak zijn. Uit de enquête komt het beeld naar voren dat toezichthou- 
ders meer energie besteden aan het naleven van regels dan aan het beoordelen van de strategische en operationele risico's van de bedrijfsactiviteiten. Dit lijkt een zorgelijke ontwikkeling, omdat hiermee het doel van de regelgeving - verbeteren van toezicht - niet wordt bereikt, terwijl door de toegenomen strategische en operationele risico's toezicht belangrijker is geworden. Een derde kanttekening kan worden geplaatst vanuit het perspectief van irrationaliteit. Indien we een denkmodel hanteren waarbij bestuurders mede op irrationele overwegingen besluiten nemen, is het logisch ook bij de toezichthouders potentiële gevolgen van irrationaliteit te onderzoeken. Morck (2004) beschrijft bijvoorbeeld een experiment over de invloed van autoriteit van Milgram uit de jaren '60 van de vorige eeuw. Een proefpersoon wordt door Milgram in een witte laboratoriumjas geïnstrueerd dat hij meewerkt aan een onderzoek naar het effect van straf op leergedrag en optreedt als leraar die stroomstoten kan geven aan een leerling, indien de leerling vragen onjuist beantwoordt. De leerling is een acteur die niet werkelijk stroomstoten ontvangt, maar de proefpersoon/leraar is hiervan niet op de hoogte. Uit het experiment blijkt dat meer dan 60 procent van de proefpersonen uiteindelijk stroomstoten van 450 volt geeft, terwijl zij weten dat dit gevaarlijk is voor de leerling. Milgram's conclusie is dat mensen een neiging hebben om autoriteit - in het experiment de persoon met de laboratoriumjas - te gehoorzamen. Morck's analogie is dat toezichthouders een vergelijkbare relatie met bestuurders hebben, waarbij loyaliteit aan de bestuurder een kritische houding bemoeilijkt. Een analyse van Mace (1971) bevestigt de ideeën van Morck, bijvoorbeeld doordat geïnterviewde toezichthouders aangeven dat het ongepast is om kritische vragen te stellen tijdens vergaderingen. Of, zoals een bestuursvoorzitter na vergadering uitlegde aan een toezichthouder die een kritische vraag stelde: "It is just plain bad manners to ask those kind of questions in a board meeting" (Mace, 1971, p. 54). Concluderend kan gesteld worden dat het toezichthoudend orgaan, de Raad van Commissarissen in Nederland, in de beste positie is om irrationaliteit van bestuurders te beteugelen, maar dat zij wellicht hierbij gehinderd worden door hun eigen irrationaliteit.

Het laatste governance-mechanisme zijn de aandeelhouders, waarbij zowel elementen van directe als indirecte disciplinering aanwezig zijn. De indirecte werking komt voort uit de dreiging voor een manager om ontslagen te worden door de vergadering van aandeelhouders. Zoals eerder toegelicht, zal dit indirecte mechanisme naar verwachting weinig effect sorteren. Aandeelhouders kunnen langs twee wegen directe invloed op de bestuurder proberen uit te oefenen: via de aandeelhoudersvergadering en buiten de vergadering om. Een klein deel van de besluiten door het ondernemingsbestuur wordt aan de vergadering voorgelegd, maar deze beslissingen betreffen belangrijke strategische keuzes. Potentieel heeft de vergadering hier een mogelijkheid om irrationele managers te beïnvloeden. Het is in dit opzicht goed om te constateren dat Nederlandse beursondernemingen in toenemende mate grote overnames aan de aandeelhouders voorleggen in buitengewone vergaderingen. ${ }^{10}$ De vergadering kent echter een grote beperking in het geven van informatie aan aandeelhouders, omdat ook concurrenten geïnformeerd zullen worden. Hierdoor hebben de aandeelhouders een grote achterstand ten opzichte van bestuurders en commissarissen. Empirisch onderzoek heeft aangetoond dat de vergadering een zeer beperkte invloed heeft. Studies in zowel de Verenigde Staten als Nederland tonen dat alleen in zeldzame gevallen wordt afgeweken van de voorstellen van het zittende management. ${ }^{11}$ Uiteraard is het ook mogelijk dat aandeelhouders buiten de aandeelhoudersvergadering om het management beïnvloeden. Echter, hiervoor is erg weinig empirisch bewijs. ${ }^{12}$

Uit het voorgaande kunnen we concluderen dat de rol van corporate governance in het beperken van de gevolgen van irrationele beslissingen zeer beperkt is. Indirecte mechanismen, waarbij managers geprikkeld worden om betere beslissingen te nemen werken niet, omdat de irrationaliteit geen bewust gedrag is. Een belangrijke rol is hier mogelijk voor het toezichthoudende orgaan, zoals de Raad van Commissarissen in Nederland, en in mindere mate voor aandeelhouders.

\section{Conclusie}

Een belangrijke ratio van corporate governance is gelegen in de irrationaliteit van topbestuurders. In deze bijdrage is angetoond dat besluitvorming in ondernemingen kan worden beïnvloed door irrationaliteit van bestuurders. Tevens is aangegeven dat deze irrationaliteit belangrijke gevolgen heeft voor de effectiviteit van governance-mechanismen. Met name de toezichthouders - in Nederland de commissarissen - kunnen een belangrijke rol spelen in het beperken van de verstorende invloed van irrationele bestuurders. 


\section{Literatuur}

Amihud, Y. en B. Lev (1981), Risk reduction as a managerial motive for conglomerate mergers, Bell Journal of Economics, vol. 12, pp. 605-617.

Ang, J.S., A. de Jong en M. van der Poel (2007), Does CEO familiarity in business segments affect their divestment decisions?, Working paper.

Baker, M., R.S. Ruback en J. Wurgler (2004), Behavioral corporate finance: A survey, Working paper.

Bazerman, M. (1998), Judgement in managerial decision making, fourth edition, John Wiley \& Sons, New York.

Becht, M., P. Bolton en A.A. Röell (2003), Corporate governance and control, in: Handbook of the economics of finance, vol. 1, part 1, G. Constantinides, M. Harris en R. Stulz (eds), Elsevier, pp. 1-109.

Berle, A.A. en G.C. Means (1932), The modern corporation and private property, MacMillan, New York.

Bertrand, M. en A. Schoar (2003), Managing with style: The effect of managers on firm policies, Quarterly journal of Economics, vol. 118, pp. 1169-1208.

Brehmer, B. (1980), In one word: Not from experience, Acta Psychologica, vol. 45, pp. 223-241.

Brounen, D., A. de Jong en K. Koedijk (2005), Theorie en praktijk van ondernemingsfinanciering: investeringsselectie, Maandblad voor Accountancy en Bedrijfseconomie, jg. 79, no. 5 (mei), pp. 229-237.

Commissie Corporate Governance (1997), Corporate governance in Nederland. De veertig aanbevelingen.

Commissie Corporate Governance (2003), De Nederlandse corporate governance code. Beginselen van deugdelijk ondernemingsbestuur en best practice bepalingen.

Davis, J.H., F.D. Schoorman en L. Donaldson (1997), Toward a stewardship theory of management, Academy of Management Review, vol. 22, pp. 20-47.

Ernst \& Young (2006), Board members on risk. Leveraging frameworks for the future.

Finkelstein, S., 2006, Why smart executives fail: Four case histories of how people learn the wrong lessons from history, Business History, vol. 48 , pp. 153-170.

Gervais, S., J.B. Heaton en T. Odean (2002), The positive role of overconfidence and optimism in investment policy, Working paper.

Gompers, P.A., J.L. Ishii en A. Metrick (2003), Corporate governance and equity prices, Quarterly Journal of Economics, vol. 118, pp. 107-155.

Graham, J.R. en C.R. Harvey (2001), The theory and practice of corporate finance: Evidence from the field, Journal of Financial Economics, vol. 61, pp. 187-243.

Hackbarth, D. (2004), Managerial traits and capital structure decisions, Working paper.

Heaton, J.B. (2002), Managerial optimism and corporate finance, Financial Management, vol. 31, pp. 33-45.

Jensen, M.C. en W.H. Meckling (1976), Theory of the firm: managerial behavior, agency costs and ownership structure, Journal of Financial Economics, vol. 3, pp. 305-360.

Jensen, M.C. (1986), Agency costs of free cash flow, corporate finance, and takeovers, American Economic Review, vol. 76, pp. 323-329.

Jensen, M.C. (2005), Agency costs of overvalued equity, Financial Management, vol. 34, pp. 5-19.

John, K. en L.W. Senbet (1998), Corporate governance and board effectiveness, Journal of Banking \& Finance, vol. 22, pp. 371-403.

Jong, A. de, G. Mertens en P. Roosenboom (2006), Shareholders' voting at general meetings: Evidence from the Netherlands, Journal of Management and Governance, vol. 10, pp. 353-380.

Kahneman, D. en A. Tversky (eds.) (2000), Choices, values and frames, Cambridge University Press, Cambridge.

Mace, M. (1971), Directors: Myth and reality, Harvard Business School Press (Harvard).

Malmendier, U. en G. Tate (2005a), CEO overconfidence and corporate investment, The Journal of Finance, vol. 60, pp. 2661-2700.

Malmendier, U. en G. Tate (2005b), Who makes acquisitions? CEO overconfidence and the markets reaction, Working paper.

Malmendier, U., G. Tate en J. Yan (2006), Corporate financial policies and overconfident managers, Working paper.

Maug, E. en K. Rydqvist (2001), What is the function of the shareholder meeting? Evidence from the U.S. proxy voting process, Working paper.

Moerland, P.W. (1997), Corporate governance. Theorie en praktijk in internationaal perspectief, Financiële en Monetaire Studies, WoltersNoordhoff, Groningen.

Monitoring Commissie Corporate Governance (2006), Reacties op vragenlijst inzake de rol van de aandeelhouders, Rapport van ministerie van Financiën.

Morck, R. (2004), Behavioral finance in corporate governance. Independent directors and non-executive chairs, Working paper.

Polak, N.J. (1931), Atavismen in en om de naamlooze vennootschap, Diësrede Tweeden Handels-Hoogeschooldag op 9 mei 1931 te Rotterdam.

Roe, M. J. (2003), Political determinants of corporate governance, Oxford University Press (New York).

Roll, R. (1986), The hubris hypothesis of corporate takeovers, Journal of Business, vol. 59, pp. 197-216.

Shefrin, H. (2007), Behavioral corporate finance. Decisions that create value, McGraw-Hill Irwin, New York.

Shleifer, A. en R.W. Vishny (1997), A survey of corporate governance, The Journal of Finance, vol. 52, pp. 737-783.

Wennekes, W. (1993), De aartsvaders. Grondleggers van het Nederlandse bedrijfsleven, Atlas, Amsterdam.

\section{Noten}

1 Naast deze governance-mechanismen worden in de literatuur concurrentie op markten voor goederen en diensten, vermogensstructuurkeuze, dividendpolitiek, prijsvorming op financiële markten, en de interne en externe kapitaalmarkt voor managers genoemd (Moerland, 1997 en Shleifer en Vishny, 1997).

2 De verklaringskracht is gemeten op basis van de gecorrigeerde $R^{2}$ (Bertrand en Schoar, 2003, p. 1182)

3 De naamgeving is een tautologie, aangezien ondernemingsfinanciering ook menselijk gedrag onderzoekt, namelijk besluitvorming door managers op het gebied van financiering van ondernemingen en de besteding van deze middelen. De tautologie geeft in ieder geval aan dat de grillen van menselijk gedrag over het algemeen nog weinig aandacht krijgen in de corporate finance literatuur.

4 Andere vormen van irrationeel gedrag zijn zeker ook relevant. Voorbeelden zijn beperkte rationaliteit en dientengevolge het gebruik 
van vuistregels. In de enquête-studies van Graham en Harvey (2001) onder Amerikaanse managers en Brounen, De Jong en Koedijk (2005) onder Europese managers blijkt bijvoorbeeld dat een groot aantal managers (56\% van de Amerikaanse en $64 \%$ van de Nederlandse respondenten) bij de selectie van investeringsprojecten de terugverdientijd als criterium hanteert, terwijl dit criterium geen rekening houdt met de tijdswaarde van geld.

5 De gevolgen van irrationaliteit in andere gebieden van de ondernemingsfinanciering zijn zeer beperkt onderzocht. Op het gebied van vermogensstructuurkeuze is een theoretische bijdrage geleverd door Hackbarth (2004) en een empirische analyse uitgevoerd door Malmendier, Tate en Yan (2006). Tevens hebben onderdelen van modellen van Heaton (2002) en Malmendier en Tate (2005a) betrekking op financieringskeuzes.

6 In de literatuur is een aantal vergelijkbare modellen en intuïties ontwikkeld door Malmendier en Tate (2005a, 2005b), Gervais, Heaton en Odean (2002) en Jensen (2005).

7 Een enkele auteur is erg optimistisch over irrationele managers. Shefrin (2007) is de auteur van het eerste tekstboek over behavioral corporate finance dat volgend jaar zal verschijnen. Het boek is een goede beschrijving van een groot aantal kuilen waar managers als gevolg van hun gedrag in kunnen vallen. Echter, de auteur lijkt zelf overoptimistisch als hij stelt "Remedies for agency conflicts tend to emphasize the manipulation of incentives. Remedies for behavioral pitfalls tend to emphasize training and process" (p. 3). Met andere woorden, voldoende training en bewustzijn over irrationeel gedrag is een remedie tegen de negatieve effecten van dit gedrag. De psycholoog Brehmer (1980) heeft in een overzichtsstudie duidelijk gemaakt dat mensen over het algemeen niet in staat zijn om te leren van hun ervaringen. De eerder besproken empirische studies naar de effecten van irrationeel gedrag vertonen tevens geen leereffecten bij de managers. Finkelstein (2006) gaat nog een stap verder een beschrijft vier voorbeelden waar managers zelfs de verkeerde lessen van hun geschiedenis leren.

8 In deze analyse wordt niet ingegaan op wet- en regelgeving op het gebied van goed ondernemingsbestuur en irrationeel gedrag. Roe (2003) besteedt expliciet aandacht aan deze problematiek. De auteur beschrijft dat wet- en regelgeving in de Verenigde Staten een zeer beperkte invloed heeft op fouten en mismanagement door bestuurders. De business judgement rule in de Verenigde Staten heeft als uitgangspunt dat bestuurders niet aansprakelijk zijn voor mismanagement. Roe stelt dat deze regel een grote tekortkoming van wet- en regelgeving is, aangezien de regels voor veel managers een uitweg bieden om niet aansprakelijk te worden gesteld door aandeelhouders (Roe, 2003, p. 171-173).

9 Zie John en Senbet (1998) voor een overzicht van literatuur over de effectiviteit van bestuur en toezicht.

10 Zo heeft Sligro bijvoorbeeld de overname van EDAH in een buitengewone vergadering voorgelegd aan haar aandeelhouders (Het Financieele Dagblad van 21 juni 2006).

11 De Jong, Mertens en Roosenboom (2006) hebben in de periode 199820021583 voorstellen op vergaderingen van Nederlandse ondernemingen onderzocht en vinden dat slechts 9 voorstellen niet worden aangenomen. In deze periode zijn alle voorstellen door het bestuur op de agenda geplaatst. In de Verenigde Staten is door Maug en Rydqvist (2001) een onderzoek gedaan naar 4931 voorstellen van het management en 1063 voorstellen van aandeelhouders, waarvan er respectievelijk 64 en 1008 niet worden aangenomen.

12 Een recent onderzoek van de Nederlandse Monitoring Commissie Corporate Governance (2006) onder 32 ondernemingen beschrijft bijvoorbeeld dat in 28 ( $88 \%$ ) ondernemingen bestuurders discussies hebben met aandeelhouders buiten de vergadering. Vijf ondernemingen (16\%) consulteren zelfs individuele grootaandeelhouders voorafgaande aan een wijziging in de strategie. VNU is een voorbeeld van individueel overleg met aandeelhouders. De onderneming legde de plannen voor de overname van IMS Health eerst aan de grootaandeelhouders voor. Doordat deze aandeelhouders bij meerderheid tegen bleken trok VNU de plannen in (Het Financieele Dagblad van 5 augustus 2006). 